Article

\title{
Combined Effects of Fertilizer, Irrigation, and Paclobutrazol on Yield and Fruit Quality of Mango
}

\author{
Babul C. Sarker ${ }^{1, *}$, Mohammad A. Rahim ${ }^{2}$ and Douglas D. Archbold ${ }^{3}$ \\ 1 Principal Scientific Officer, Pomology Division, Horticulture Research Centre, Bangladesh Agricultural \\ Research Institute, Joydebpur, Gazipur 1701, Bangladesh \\ 2 Department of Horticulture, Bangladesh Agricultural University, Mymensingh 2202, Bangladesh; \\ marahim1956@yahoo.com \\ 3 Department of Horticulture, University of Kentucky, Lexington, KY 40546-0091, USA; darchbol@uky.edu \\ * Correspondence: bsarker_64@yahoo.com; Tel.: +88-02-9261491
}

Academic Editor: Astrid Forneck

Received: 29 June 2016; Accepted: 29 September 2016; Published: 11 October 2016

\begin{abstract}
Combinations of fertilizer rates, foliar N sprays, irrigation practices, and paclobutrazol were studied to determine how much they could alter and/or improve mango (Mangifera indica L.) growth, flowering, and yield. Two treatment combinations derived from several years of prior studies of individual practices were compared: one combination was comprised of the best (BT) individual practices from the prior studies and included three applications of fertilizer, a $4 \% \mathrm{KNO}_{3}$ spray application before flowering, paclobutrazol at $7.5 \mathrm{~g} / \mathrm{L}$, and weekly irrigation, and the other combination was comprised of the next best (NB) individual practices including two applications of the same amount of fertilizer, a $4 \%$ urea spray before flowering, paclobutrazol at $10.0 \mathrm{~g} / \mathrm{L}$, and biweekly irrigation. Both combinations significantly reduced terminal shoot growth and leaves per terminal shoot, advanced the date of flowering and harvest, increased panicle number, length and secondary branching, increased fruit set, fruit number at harvest, fruit size, and yield, with BT producing larger fruit and a greater yield than NB. Although both combinations produced fruit with higher quality than the control, the BT combination produced fruit with the higher total soluble solids, reducing, non-reducing, and total sugar content, and vitamin $C$ content than the NB combination. Both BT and NB combinations of the optimums identified in the prior studies were successful at advancing bloom and harvest and increasing yield more than any of the optimum individual components alone, by 14-fold more than untreated trees for the BT combination, suggesting there were additive, if not synergistic, effects on mango. Further studies are warranted to assess the sustainability of these effects over longer periods of time, and to ascertain if the effects occur across mango cultivars and production environments.
\end{abstract}

Keywords: paclobutrazol; soil drenching; panicle emergence; flowering; peel-pulp ratio

\section{Introduction}

Mango (Mangifera indica L.) is a delicious fruit which belongs to the family Anacardiaceae. The principal mango producing countries are India, China, Thailand, Indonesia, and Pakistan [1]. In Bangladesh, which ranks ninth, about 242,605 tons of fruit are produced from an area of 51,012 ha, with an average yield of 4.75 tons per ha [2], although it falls short of fulfilling national demand. Irregular flowering, low fruit set, as well as fruit retention leading to low yield, fruit of poor quality, and a short harvest period are the main hindrances to increasing mango availability. Optimizing and integrating various key management practices such as fertilizer application, irrigation, foliar sprays of $\mathrm{KNO}_{3}$ or urea, and soil drench application of paclobutrazol might extend the availability period and increase yield and quality. Many mango growers in Bangladesh do not employ these management 
practices on an annual basis, or have few guidelines for optimizing them, and need a set of recommendations to increase and sustain production.

Yearly soil application of N, P, and $\mathrm{K}$ has markedly increased the number of mango fruit per plant, fruit weight, yield, and fruit quality [3-7]. Effective rates of $\mathrm{N}, \mathrm{P}$ and $\mathrm{K}$ have ranged from 0.4 to $0.8 \mathrm{~kg}$ per tree. Foliar $\mathrm{KNO}_{3}$ applications have also advanced flowering and harvest date, increased yield, and reduced alternate bearing in mango [8,9]. Maximum yield was found by foliar urea application [10]. Potassium nitrate, especially in combination with urea, produced good results on flowering and yield parameters [11]. Irrigation of mango trees can be beneficial, as it has been shown to reduce fruit drop resulting in satisfactory production [12]. However, in Bangladesh, bearing trees are often irrigated only after fruit set and thereafter at fortnight intervals, but not all growers practice this.

Soil application of the growth retardant paclobutrazol was reported to reduce tree growth and induce precocious flowering, fruit set, fruit retention, and increase yield in bearing mango trees [13,14]. In addition, improvements in fruit quality parameters, such as ascorbic acid, total sugar, reducing sugar, and total soluble solids content, have also been observed [14-17].

A series of studies assessing strategies of soil and foliar fertilization, irrigation, and soil application of paclobutrazol were carried out to identify the best treatments for optimizing mango yield, fruit quality, and harvest period, and to be used to develop management recommendations. Cow manure, widely available to mango growers in Bangladesh, was studied as a soil fertilizer. It comprised $13.8 \mathrm{~g} \mathrm{~N} / \mathrm{kg}, 3.2 \mathrm{~g} \mathrm{P} / \mathrm{kg}, 0.36 \mathrm{~g} \mathrm{~K} / \mathrm{kg}, 0.13 \mathrm{~g} \mathrm{~S} / \mathrm{kg}$, and $0.02 \mathrm{~g} \mathrm{Zn} / \mathrm{kg}$, and was applied at 12.5 to $37.5 \mathrm{~kg}$ per tree in 1, 2, or 3 separate installments over several months [18]. The highest rate, split into three applications, produced the highest number of fruit, total yield, and fruit quality, and delayed the start of harvest by 11 days. To determine if foliar nutrient application was beneficial, $\mathrm{KNO}_{3}$ at $4 \%, 6 \%$ and $8 \%(\mathrm{w} / \mathrm{v})$, and urea at $2 \%$ and $4 \%(\mathrm{w} / \mathrm{v})$, were applied before flowering on 15 November $2007 . \mathrm{KNO}_{3}$ at $4 \%$ exhibited the highest yield, and fruit vitamin C and total soluble solids (TSS) content, followed by urea at $4 \%$ [19], with both advancing the start of harvest by 5 days. Regular irrigation starting at fruit set prevented fruit drop and improved fruit in size and quality [20]. To determine which irrigation strategies had significant impacts on fruit yield and quality, trees were irrigated on 15 October and 15 November 2007 and then from fruit set to maturity at 7, 14, or 21 day intervals versus no irrigation. Plants irrigated twice on 15 October and 15 November 2007 and then from fruit set to maturity at 7 and 14 day intervals produced about two-fold higher yields (22.2 and $21.6 \mathrm{~kg} / \mathrm{plant}$, respectively) and the best quality [21], and delayed the start of harvest by 7 days. Paclobutrazol applied at $7.5 \mathrm{~g} / \mathrm{L}$ on 15 October 2007 produced the highest number of fruits as well as greatest yield per plant fruit weight, and had the best quality, compared to lower and higher rates and a December application, with harvest starting about 15 days earlier. A subsequent study indicated that a July application of paclobutrazol at $7.5 \mathrm{~g} / \mathrm{L}$ or $10.0 \mathrm{~g} / \mathrm{L}$ significantly advanced harvest by 22 days over control and produced 4.7-fold higher yield and bigger fruit over control.

After having assessed the cultural practices individually, combinations of the optimum individual practices were assessed to determine if they were additive or synergistic in their effects on tree growth and components of yield. Thus, an integrated experiment with split applications of fertilizer, $\mathrm{KNO}_{3}$ and urea sprays, periodic irrigation, and soil drench applications of paclobutrazol was performed, combining the best individual practices from the previous studies as one treatment, and the second best practices as another treatment, to determine effects on mango yield and fruit quality.

\section{Materials and Methods}

\subsection{Location}

The experiment was carried out at the Bangladesh Agricultural University (BAU) Germplasm Centre, Department of Horticulture, Mymensingh, Bangladesh which is located at $24^{\circ} 26^{\prime}$ latitude and $90^{\circ} 15^{\prime}$ longitude with an altitude of $8.3 \mathrm{~m}$ above sea level. Biochemical analyses were carried out in the Department of Biochemistry of Bangladesh Agricultural University (BAU), Mymensingh, Bangladesh. 


\subsection{Soil and Climate}

The soil at the Germplasm Centre is sandy loam which belongs to the Old Brahmaputra Flood Plain Alluvial Tract [22]. The selected soil samples of the experimental area were analyzed at the Laboratory of the Soil Science Division, Bangladesh Agricultural Research Institute, Joydebpur, Gazipur. Soil $\mathrm{pH}$ was 6.5 and 6.3 at a depth of $0-15 \mathrm{~cm}$ and $15-30 \mathrm{~cm}$, respectively. The total \%N, available $\mathrm{P}$, and available $\mathrm{K}$ were $0.056,38 \mu \mathrm{g} / \mathrm{mL}$ and $0.10 \mathrm{meq} / 100 \mathrm{~mL}$ at a soil depth of $0-15 \mathrm{~cm}$, respectively, and $0.036,13 \mu \mathrm{g} / \mathrm{mL}$ and $0.07 \mathrm{meq} / 100 \mathrm{~mL}$ at a soil depth of $15-30 \mathrm{~cm}$, respectively. The experimental site enjoys a sub-tropical climate characterized by heavy rainfall (means of $361 \mathrm{~mm} / \mathrm{month}$ and $2166 \mathrm{~mm}$ total), high temperature (mean $28.34^{\circ} \mathrm{C}$ ), a mean of $161 \mathrm{~h} /$ month of sun during April to September, and scant rainfall (mean $79 \mathrm{~mm} /$ month and $555 \mathrm{~mm}$ total), low temperature $\left(22.6^{\circ} \mathrm{C}\right.$ ) and a mean of $187 \mathrm{~h} /$ month of sun during October to March (Source: Weather Yard, Department of Irrigation and Water Management, BAU, Mymensingh, Bangladesh, 2005).

\subsection{Experimental Material}

The cultivar used in the study, Amrapali (BARI Mango-3), is precocious, medium dwarf, annual, and prolific in bearing and has good fruit quality [23]. The age of the plants was 11 years at the initiation of experiment. Plant spacing was $5 \mathrm{~m} \times 5 \mathrm{~m}$.

\subsection{Experimental Design}

The experiment was laid out in a Randomized Complete Block Design (RCBD) with 3 replications. The treatments were: (1) the best (BT) individual treatments of fertilizer (37.5 kg cow dung with $518.43 \mathrm{~g} \mathrm{~N}, 120 \mathrm{~g} \mathrm{P}, 187.5 \mathrm{~g} \mathrm{~K}, 67.45 \mathrm{~g} \mathrm{~S}$, and $8.09 \mathrm{~g}$ Zn per plant) applied in three installments, a $4 \% \mathrm{KNO}_{3}$ spray application on 15 November 2007 approximately 1.5 to 2 months prior to anticipated flowering, irrigation on 15 October and 15 November 2007 and then continued from fruit set (6 March 2008) to maturity at 7 day intervals, soil drench application of paclobutrazol at $7.5 \mathrm{~g} / \mathrm{L}$ of active ingredient on 15 July 2007 (all of the best treatments from prior studies); (2) the 2nd or next best (NB) individual treatments of fertilizer (same as above) applied in two installments, a $4 \%$ urea spray application on 15 November 2007 approximately 1.5 to 2 months prior to anticipated flowering, irrigation on 15 October and 15 November 2007 and then continued from fruit set to maturity at 14 day intervals, and a soil drench application of paclobutrazol at $10 \mathrm{~g} / \mathrm{L}$ of active ingredient on 15 July 2007; and (3) untreated control.

\subsection{Application of Fertilizer and Paclobutrazol}

Fertilizer was applied in two or three applications. The first application was the total amount of cow dung, triple superphosphate (TSP), gypsum, and zinc sulfate applied on 15 September. If in two applications, $\frac{1}{2}$ of the urea and muriate of potash $(\mathrm{MoP})$ were applied on 15 September and the remainder was applied on 15 March. If in three applications, $\frac{1}{4}$ of the total amounts of urea and MoP were applied on 15 March and again at the 3rd application on 15 May. Very light irrigation was provided at each time of fertilizer application.

Paclobutrazol (Syngenta, India) was prepared from a $25 \%(\mathrm{w} / \mathrm{v})$ stock solution for final concentrations of 7.5 and $10 \mathrm{~g} / \mathrm{L}$ of active ingredient. Treatments were applied as a soil drench in which 10 small holes (10-15 cm depth) were prepared in the soil around the collar region of the trees just inside the fertilizer ring [24]. One liter of the prepared solutions was poured into the holes of each tree, and the soil was reworked after application. Only water was applied to the control plants.

\subsection{Tree Growth and Yield Measurements}

The length and number leaves of 10 randomly-selected terminal shoots at flowering on 20 December 2007 were measured. The individual leaf area of 50 leaves was measured, taking 5 from each of the 10 above-selected shoots, using a leaf area meter and was expressed as $\mathrm{cm}^{2}$. Starting at 
the first appearance of a panicle, the number of panicles per plant was counted at 10 day intervals up to completion of panicle emergence. Ten panicles were randomly selected from each treatment on 18 February 2008, and the length and number of secondary branches per panicle was recorded. The initial number of fruit of each panicle, and the fruit retained per panicle were counted at 10 day intervals starting from the pea stage up to harvest starting from 6 March 2008. The average date of harvest (when one or two ripe fruit dropped from the tree, all the fruit were harvested at one time), number of fruit/tree, fruit weight, and total yield/tree was recorded.

\subsection{Fruit Quality Measurements}

After harvest, 10 randomly-selected fruit per tree were ripened at room temperature, and fruit quality was determined. Each fruit was peeled, the stone removed, and each was weighed along with the remaining pulp. The edible (pulp) portion, stone-to-pulp ratio, peel-to-pulp ratio, shelf-life (the difference between the harvest date and the date up to which the fruit remained edible was considered as shelf life), total soluble solids (TSS), titratable acidity, vitamin C, dry matter, and reducing, non-reducing, and total sugar content. TSS of the pulp was measured using a hand refractometer. The titratable acidity of mango pulp was determined [25] using $0.1 \mathrm{~N} \mathrm{NaOH}$ solution. Vitamin C content was determined [26]. Reducing sugar content of mango pulp was determined by the dinitrosalicylic acid method [27]. The total sugar content of mango pulp was colorimetrically determined by the anthrone method [28].

\subsection{Statistical Analysis}

Treatment means were analyzed by analysis of variance and separated by Fisher's Least Significant Difference (LSD) test at $p=0.05$ [29].

\section{Results}

\subsection{Tree Growth}

Both BT and NB had similar effects of reducing terminal shoot length and increasing panicle length and the number of secondary branches per panicle (Table 1). The NB treatment had the fewest leaves per terminal shoot, although the BT treatment also reduced terminal shoot length. The NB treatment only had the smallest leaf dimensions and area per leaf. Interestingly, the BT combination had the widest panicles.

Table 1. Effects of combinations of growth regulator and management practices on leaf, shoot and panicle characters of mango. Treatments were the combinations of the best and next best treatments from prior studies, as defined in the text.

\begin{tabular}{|c|c|c|c|c|c|c|c|c|}
\hline \multirow{2}{*}{$\begin{array}{l}\text { Treatment } \\
\text { Combination }\end{array}$} & \multirow{2}{*}{$\begin{array}{l}\text { Length of } \\
\text { Terminal } \\
\text { Shoot }(\mathrm{cm})\end{array}$} & \multirow{2}{*}{$\begin{array}{c}\text { Leaves per } \\
\text { Terminal } \\
\text { Shoot }\end{array}$} & \multicolumn{3}{|c|}{ Leaf } & \multirow{2}{*}{$\begin{array}{l}\text { Length of } \\
\text { Panicle } \\
\text { (cm) }\end{array}$} & \multirow{2}{*}{$\begin{array}{l}\text { Width of } \\
\text { Panicle } \\
\quad(\mathrm{cm})\end{array}$} & \multirow{2}{*}{$\begin{array}{c}\text { Secondary } \\
\text { Branches } \\
\text { per Panicle }\end{array}$} \\
\hline & & & $\begin{array}{l}\text { Length } \\
(\mathrm{cm})\end{array}$ & $\begin{array}{l}\text { Width } \\
\text { (cm) }\end{array}$ & $\begin{array}{l}\text { Area } \\
\left(\mathrm{cm}^{2}\right)\end{array}$ & & & \\
\hline Control & $16.3 \mathrm{a}^{\mathrm{z}}$ & $12.5 \mathrm{a}$ & $22.6 \mathrm{a}$ & $4.5 \mathrm{a}$ & $63.1 \mathrm{a}$ & $22.9 \mathrm{~b}$ & $17.1 \mathrm{~b}$ & $24.8 \mathrm{~b}$ \\
\hline Best & $14.2 \mathrm{~b}$ & $9.3 \mathrm{c}$ & $21.1 \mathrm{a}$ & $4.4 \mathrm{a}$ & $60.9 \mathrm{a}$ & $28.1 \mathrm{a}$ & $19.1 \mathrm{a}$ & $32.7 \mathrm{a}$ \\
\hline Next Best & $12.8 \mathrm{~b}$ & $8.4 \mathrm{~b}$ & $19.2 \mathrm{c}$ & $3.8 \mathrm{~b}$ & $52.3 \mathrm{~b}$ & $26.9 \mathrm{a}$ & $17.5 \mathrm{~b}$ & $31.7 \mathrm{a}$ \\
\hline LSD (0.05) & 1.5 & 0.8 & 1.89 & 0.4 & 5.8 & 1.6 & 1.3 & 3.3 \\
\hline
\end{tabular}

\subsection{Emergence, Number of Panicles, Fruit Set, and Fruit Retention}

The first panicle emerged 49 and 44 days earlier for the BT and NB treatment combinations, respectively, than the control (Table 2). The BT combination produced more panicles per plant from emergence until equaled by the NB combination on the final measurement date.

Initial fruit set was greater for both treatments than the control (Table 3). From 26 March to harvest, the BT combination had 2-fold greater fruit retained per panicle followed by the NB combination than the control. 
Table 2. Effects of combinations of growth regulator and management practices on emergence and number of panicles per plant of mango. Treatments were the combinations of the best and next best treatments from prior studies, as defined in the text.

\begin{tabular}{|c|c|c|c|c|c|c|c|}
\hline \multirow[b]{2}{*}{$\begin{array}{c}\text { Treatment } \\
\text { Combination }\end{array}$} & \multirow[b]{2}{*}{$\begin{array}{c}\text { Date of Appearance } \\
\text { of First Panicle }\end{array}$} & \multicolumn{6}{|c|}{ Number of Panicles per Plant at } \\
\hline & & $\begin{array}{c}30 \\
\text { December } \\
2007\end{array}$ & $\begin{array}{c}9 \\
\text { January } \\
2008\end{array}$ & $\begin{array}{c}19 \\
\text { January } \\
2008\end{array}$ & $\begin{array}{c}29 \\
\text { January } \\
2008\end{array}$ & $\begin{array}{c}8 \\
\text { February } \\
2008\end{array}$ & $\begin{array}{c}18 \\
\text { February } \\
2008\end{array}$ \\
\hline Control & 7 & $0 c^{z}$ & $0 \mathrm{c}$ & $0 \mathrm{c}$ & 0 & $6.8 \mathrm{~b}$ & $32.0 \mathrm{~b}$ \\
\hline Best & 20 December 2007 & $15.0 \mathrm{a}$ & $48.3 \mathrm{a}$ & $96.0 \mathrm{a}$ & $148.8 \mathrm{a}$ & $189.5 \mathrm{a}$ & $197.7 \mathrm{a}$ \\
\hline Next Best & 25 December 2007 & $9.4 \mathrm{~b}$ & $30.0 \mathrm{~b}$ & $88.0 \mathrm{~b}$ & $134.3 \mathrm{~b}$ & $180.2 \mathrm{a}$ & $191.6 \mathrm{a}$ \\
\hline LSD (0.05) & - & 1.4 & 3.9 & 7.1 & 10.1 & 12.9 & 16.0 \\
\hline
\end{tabular}

${ }^{\mathrm{z}}$ Means followed by different letters within columns significantly differ by Fisher's LSD at $p=0.05$.

Table 3. Effects of combinations of growth regulator and management practices on fruit set and fruit retention per panicle. Treatments were the combinations of the best and next best treatments from prior studies, as defined in the text.

\begin{tabular}{ccccccccccc}
\hline \multirow{2}{*}{ Treatments } & \multirow{2}{*}{$\begin{array}{c}\text { Fruit Set } \\
\text { per Panicle }\end{array}$} & \multicolumn{7}{c}{ Number of Fruit Retained per Panicle in 2008 at } \\
\cline { 3 - 10 } & & 16 March & 26 March & 5 April & 15 April & 25 April & 5 May & 15 May & 25 May & Harvest \\
\hline Control & $6.54 \mathrm{~b}^{\mathrm{z}}$ & $5.87 \mathrm{~b}$ & $2.65 \mathrm{c}$ & $1.75 \mathrm{~b}$ & $1.45 \mathrm{c}$ & $1.17 \mathrm{c}$ & $1.10 \mathrm{c}$ & $1.00 \mathrm{c}$ & $0.90 \mathrm{c}$ & $0.82 \mathrm{c}$ \\
Best & $10.83 \mathrm{a}$ & $10.42 \mathrm{a}$ & $5.25 \mathrm{a}$ & $4.50 \mathrm{a}$ & $3.53 \mathrm{a}$ & $2.43 \mathrm{a}$ & $2.22 \mathrm{a}$ & $2.15 \mathrm{a}$ & $2.10 \mathrm{a}$ & $2.05 \mathrm{a}$ \\
Next Best & $10.17 \mathrm{a}$ & $9.62 \mathrm{a}$ & $3.42 \mathrm{~b}$ & $2.87 \mathrm{ab}$ & $1.97 \mathrm{~b}$ & $1.67 \mathrm{~b}$ & $1.67 \mathrm{~b}$ & $1.65 \mathrm{~b}$ & $1.62 \mathrm{~b}$ & $1.62 \mathrm{~b}$ \\
LSD (0.05) & 1.34 & 1.09 & 0.62 & 1.64 & 0.32 & 0.34 & 0.20 & 0.13 & 0.17 & 0.18 \\
\hline \multicolumn{7}{r}{$\mathrm{z}$} & Means followed by different letters within columns significantly differ by Fisher's LSD at $p=0.05$.
\end{tabular}

\subsection{Harvest, Fruit Yield, and Fruit Characters}

The harvest date was three or more weeks earlier for the treatment combinations than the control (Table 4). The BT combination produced the most and largest fruit, and total yield (Figure 1), followed by the NB combination, and both were significantly greater than the control. In fact, the BT combination produced 8 -fold more fruit, and fruit weight was $61 \%$ greater, than the control. Fruit dimensions for both combinations were greater than the control but did not differ. The BT combination produced a higher edible portion than the control, with the NB combination intermediate between them. The stone:pulp ratio and peel:pulp ratio was lowest in the BT combination, followed by the NB combination, and was highest in the control. Both treatment combinations increased shelf life compared to controls.

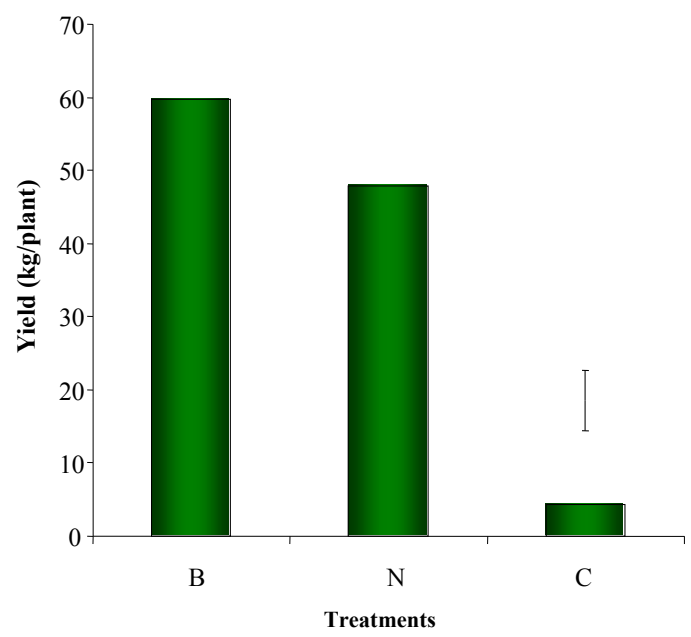

Figure 1. Effects of combinations of growth regulator and management practices on yield per plant of mango. Treatments were the combinations of the best (BT) and next best (NB) treatments from prior studies, as defined in the text. Vertical bar represents LSD at $p=0.05$. 
Table 4. Effects of combinations of growth regulator and management practices on number of fruit and fruit characters of mango. Treatments were the combinations of the best and next best treatments from prior studies, as defined in the text.

\begin{tabular}{|c|c|c|c|c|c|c|c|c|c|c|}
\hline \multirow[b]{2}{*}{ Treatment } & \multirow[b]{2}{*}{$\begin{array}{l}\text { Date of } \\
\text { Harvest }\end{array}$} & \multirow[b]{2}{*}{$\begin{array}{l}\text { Number of } \\
\text { Fruit per Plant }\end{array}$} & \multicolumn{4}{|c|}{ Fruit } & \multirow[b]{2}{*}{$\begin{array}{c}\text { Edible } \\
\text { Portion (\%) }\end{array}$} & \multirow[b]{2}{*}{$\begin{array}{l}\text { Stone:pulp } \\
\text { Ratio }\end{array}$} & \multirow[b]{2}{*}{$\begin{array}{l}\text { Peel:pulp } \\
\text { Ratio }\end{array}$} & \multirow[b]{2}{*}{$\begin{array}{l}\text { Shelf Life } \\
\text { (days) }\end{array}$} \\
\hline & & & $\begin{array}{c}\text { Weight } \\
\text { (g) }\end{array}$ & $\begin{array}{l}\text { Length } \\
\text { (cm) }\end{array}$ & $\begin{array}{c}\text { Breadth } \\
(\mathrm{cm})\end{array}$ & $\begin{array}{l}\text { Thickness } \\
\text { (cm) }\end{array}$ & & & & \\
\hline Control & 1 July 2008 & $23 c^{z}$ & $191.0 \mathrm{c}$ & $9.1 \mathrm{~b}$ & $6.4 \mathrm{~b}$ & $5.9 \mathrm{~b}$ & $63.9 \mathrm{~b}$ & $0.3 \mathrm{a}$ & $0.3 \mathrm{a}$ & $8.7 \mathrm{~b}$ \\
\hline Best & 4 June 2008 & $197 a$ & $307.8 \mathrm{a}$ & $10.7 \mathrm{a}$ & $7.5 \mathrm{a}$ & $6.6 \mathrm{a}$ & $69.5 \mathrm{a}$ & $0.2 \mathrm{~b}$ & $0.2 \mathrm{~b}$ & $9.8 \mathrm{a}$ \\
\hline Next Best & 6 June 2008 & $175 \mathrm{~b}$ & $278.8 \mathrm{~b}$ & $10.3 \mathrm{a}$ & $7.4 \mathrm{a}$ & $6.5 \mathrm{a}$ & $67.0 \mathrm{ab}$ & $0.2 \mathrm{~b}$ & $0.2 \mathrm{~b}$ & $9.6 \mathrm{a}$ \\
\hline $\operatorname{LSD}(0.05)$ & & 16 & 23.2 & 1.0 & 0.4 & 0.4 & 4.0 & $<0.1$ & $<0.1$ & 0.7 \\
\hline
\end{tabular}

${ }^{\mathrm{z}}$ Means followed by different letters within columns significantly differ by Fisher's LSD at $p=0.05$.

\subsection{Fruit Quality}

The BT combination exhibited the highest TSS, but NB did not differ from the control (Table 5). The NB combination had a higher pulp pH than the control, with the BT combination similar to both. Both combination treatments had lower titratable acidity and moisture content, and higher vitamin $C$ content, than the control, but did not differ from one another. The BT combination produced higher dry matter content, and reducing sugar, non-reducing sugar, and total sugar content than the NB combination, which was greater than the control.

\section{Discussion}

Both BT and NB combinations significantly impacted mango vegetative growth, flowering, and fruiting. While both were expected to differ from untreated trees, the primary question was whether they differed from one another, as one was comprised of the best individual treatments from prior studies while the other was comprised of the next best treatments, as the names indicate. The treatments differed in their components in some important ways. Both had equal levels of fertilizer applied, but it was applied in three installments in $\mathrm{BT}$ and only two in $\mathrm{NB}$. $\mathrm{KNO}_{3}$ was foliar-applied in BT, while urea was used at the same concentration in NB. For the NB combination, trees were less frequently irrigated from fruit set to maturity and had a higher rate of paclobutrazol included than the BT combination. While each component had effects on vegetative growth, flowering, and/or fruiting individually, it was not known how they might additively and/or synergistically interact to affect these traits.

Both combination treatments reduced vegetative growth compared to the control (Table 1). Our prior study had shown that paclobutrazol, regardless of concentration, caused a marked reduction in terminal shoot length, leaf number per terminal shoot, and leaf area compared to a control, but that reductions were at a maximum at a high concentration $(10.0 \mathrm{~g} / \mathrm{L})$ [30]. However, the NB combination in this study had a higher paclobutrazol concentration than the BT, but it did not reduce terminal shoot growth more; although leaves per shoot, and leaf length, width, and area, were reduced more. The reduction in mango growth by paclobutrazol may be due to enhanced total phenolic content of terminal buds and alteration of the phloem-to-xylem ratio of the stem, altering assimilate partitioning and patterns of nutrient supply [31]. Soil-applied paclobutrazol reduced gibberellin production and growth in new mango shoots [32,33]. Less frequent irrigation reduced mango terminal shoot growth in our prior work [21] but both irrigation levels produced the same growth in the present study, and both grew less than the unirrigated control, so irrigation level was not a factor affecting growth.

Earlier flowering and greater panicle production were promoted by both BT and NB treatments (Table 2), although BT flowered earlier and increased panicle number in the first weeks of flowering more than NB. The reduction in shoot growth may have increased total available carbohydrates, and a higher $\mathrm{C}: \mathrm{N}$ ratio in the shoots favors flower bud initiation in mango [34]. The flowering response was also likely due to the foliar $\mathrm{KNO}_{3}$ and urea applications [19]. Others have shown similar responses to $\mathrm{KNO}_{3}$ treatment $[8,35]$. The response to $\mathrm{KNO}_{3}$ may be mediated, not by increasing $\mathrm{N}$ in the tissue, but by promoting ethylene biosynthesis which affects floral induction in mango [36]. Paclobutrazol also induced earlier flowering and greater panicle production in our earlier study [30]. In contrast, more frequent irrigation caused a slight delay in date of flowering [21]. 
Initial fruit set per panicle was similar in both treatments, but the number of fruit retained by BT was greater than by NB from early in the fruiting period until harvest (Table 4), as previously observed for paclobutrazol treatment [30], $\mathrm{KNO}_{3}$ and urea treatments [19], and in response to irrigation [21]. The same response was noticed to paclobutrazol, and found that treated trees had higher reserves which enhanced fruit set compared to low reserves and low fruit set in untreated trees [17].

Both combination treatments advanced harvest date by $24-26$ or more days in the present work (Table 4). Paclobutrazol alone can cause this, as found by [37] and in our prior work, although only by 10 to 15 days [30]. $\mathrm{KNO}_{3}$ and urea treatment also advanced harvest date although only by 5 days [19], but irrigation delayed it by 7 days [21]. Interestingly, the differences in harvest dates were less, 27-29 days, than the differences in the first bloom dates, 44-49 days.

The BT combination increased yield by 14 -fold and the NB combination by 11 -fold over control trees, with BT yield significantly greater than NB yield (Figure 1). These increases far exceeded the response to each treatment component alone $[18,19,21,30]$, when yield increases ranged from 2-fold to 7 -fold greater than control trees. The present results are a strong indication that the combinations provided additive impacts on yield.

The increased total yield was the result of effects on both fruit per plant and mean fruit weight. All treatments alone also increased fruit number and yield $[18,19,21,30]$. The increased fruit weight in the combination treatments might be due to an increased rate of photosynthesis and an increase in chlorophyll content. Paclobutrazol increased leaf water use efficiency by increasing the rate of photosynthesis for a given level of leaf stomatal conductance or transpiration [38]. An increase in fruit weight and yield per tree from paclobutrazol has been reported in several studies with different mango varieties [13,17,39-41], from $\mathrm{KNO}_{3}$ [42] and urea application [10], and from increased fertilizer application [43].

Both treatments exhibited better physico-chemical characteristics (pulp percentage, stone percentage, peel percentage, total soluble solids, titratable acidity, ascorbic acid, total reducing and non-reducing sugar) compared to the control, similar to the reports by others with the individual and/or combined treatments $[4,14,15,44]$.

\section{Conclusions}

This paper represents the culmination of a set of studies on the effects of individual management practices in fertilization, foliar $\mathrm{N}$ application, irrigation, and paclobutrazol application to identify the optimum for each alone. Both combinations significantly reduced shoot growth, likely due to the presence of the growth retardant paclobutrazol, and shifted the bloom and harvest dates to earlier times. Although both combinations produced more fruit that also had higher quality than the control, the BT combination produced a greater yield and fruit with a higher total soluble solids, reducing, non-reducing, and total sugar content, and vitamin $\mathrm{C}$ content than the NB combination. The BT and NB combinations of the optimums identified in the prior studies were successful at advancing bloom and harvest and increasing yield more than any of the optimum individual componentsalone (Table 6), suggesting there were additive, if not synergistic, effects on mango. Although the present results are clear, indicating that implementation of these combinations of treatments could increase yield and ensuing economic returns very significantly over use of a single treatment, there are important considerations that need to be addressed. Given the low replication number and single year of data with a single cultivar, it is not known if similar responses will occur on broader plantings of "Amrapali" (BARI Mango-3) or other mango cultivars, or under different edaphic or environmentalconditions. In addition, the long-term sustainability of the responses to the treatment combinations should be studied, as well as the possible carryover of effects of the treatments, especially to soil-applied nutrients and to paclobutrazol, into the year(s) after application. This might be a concern if there was a cumulative effect from several years of application. Nonetheless, the "packages" of treatments appeared superior to any one treatment alone, and warrant further study to answer these additional issues. 
Table 5. Effects of combinations of growth regulator and management practices on quality attributes of mango. Treatments were the combinations of the best and next best treatments from prior studies, as defined in the text.

\begin{tabular}{|c|c|c|c|c|c|c|c|c|c|}
\hline Treatments & TSS (\%) & $\mathrm{pH}$ & $\begin{array}{c}\text { Titratable } \\
\text { Acidity (\%) }\end{array}$ & $\begin{array}{c}\text { Vitamin C } \\
\text { (mg/100 g pulp) }\end{array}$ & $\begin{array}{c}\text { Moisture } \\
\text { Content (\%) }\end{array}$ & $\begin{array}{l}\text { Dry Matter } \\
\text { Content (\%) }\end{array}$ & $\begin{array}{l}\text { Reducing } \\
\text { Sugars (\%) }\end{array}$ & $\begin{array}{l}\text { Non-Reducing } \\
\text { Sugars }(\%)\end{array}$ & $\begin{array}{c}\text { Total } \\
\text { Sugars }(\%)\end{array}$ \\
\hline Control & $24.8 \mathrm{~b}^{\mathrm{z}}$ & $5.74 \mathrm{~b}$ & $0.23 \mathrm{a}$ & $29.4 \mathrm{~b}$ & $81.9 \mathrm{a}$ & $17.9 \mathrm{c}$ & $4.8 \mathrm{c}$ & $12.8 \mathrm{c}$ & $17.5 \mathrm{c}$ \\
\hline Best & $28.7 \mathrm{a}$ & $5.89 \mathrm{ab}$ & $0.18 \mathrm{~b}$ & $35.9 \mathrm{a}$ & $77.7 \mathrm{~b}$ & $22.3 \mathrm{a}$ & $5.4 \mathrm{a}$ & $14.5 \mathrm{a}$ & $19.9 \mathrm{a}$ \\
\hline LSD (0.05) & 1.9 & 0.16 & 0.01 & 1.2 & 1.4 & 1.1 & 0.2 & 0.6 & 0.7 \\
\hline
\end{tabular}

Table 6. Summary of major effects of the individual factors and their combination on key yield traits. The top individual treatment of each pair was considered the best and was included in the Best combination, and the next best treatment was included in the Next Best combination.

\begin{tabular}{|c|c|c|c|c|}
\hline Treatment & $\begin{array}{l}\text { Advance }(-) \text { or Delay }(+) \text { Relative to Control } \\
\text { in Date of First Panicle Date of First Harvest }\end{array}$ & $\begin{array}{l}\text { Final Fruit per } \\
\text { Panicle }\end{array}$ & Fruit Weight (g) & Yield vs. Control \\
\hline Fertilizer in 3 applications ${ }^{\mathrm{z}}$ & +11 & 1.87 & 217 & $5.6 \mathrm{X}$ more \\
\hline Fertilizer in 2 applications & -3 & 1.74 & 201 & 4.6X more \\
\hline Control & 0 & 0.62 & 161 & - \\
\hline $4 \% \mathrm{KNO}_{3} \mathrm{y}$ & -18 & 1.63 & 193 & $2.5 \mathrm{X}$ more \\
\hline $4 \%$ Urea & -14 & 1.37 & 203 & $2.2 \mathrm{X}$ more \\
\hline Control & 0 & 0.73 & 175 & - \\
\hline Irrigation at 7 day intervals $x$ & +10 & 1.47 & 183 & $1.7 \mathrm{X}$ more \\
\hline Irrigation at 14 day intervals & +10 & 1.17 & 187 & $1.7 \mathrm{X}$ more \\
\hline Control & 0 & 0.57 & 169 & - \\
\hline Paclobutrazol $7.5 \mathrm{~g} / \mathrm{L}^{\mathrm{w}}$ & -22 & 2.00 & 304 & $4.7 \mathrm{X}$ more \\
\hline Paclobutrazol $10.0 \mathrm{~g} / \mathrm{L}$ & -22 & 1.70 & 261 & $3.4 \mathrm{X}$ more \\
\hline Control & 0 & 0.63 & 178 & - \\
\hline Best & -25 & 2.05 & 308 & $14 \mathrm{X}$ more \\
\hline Next Best & -25 & 1.62 & 279 & $11 \mathrm{X}$ more \\
\hline Control & 0 & 0.82 & 191 & - \\
\hline
\end{tabular}

${ }^{\mathrm{z}}$ From [18]; ${ }^{\mathrm{y}}$ From [19]; ${ }^{\mathrm{x}}$ From [21]; ${ }^{\mathrm{w}}$ From [45]. 
Acknowledgments: The author is grateful to the authorities at the Bangladesh Agricultural Research Institute (BARI) for awarding the scholarship and deputation to complete the research work which led to the Ph.D. The author extends his special thanks to the authorities of the Bangladesh Agricultural University (BAU) Germplasm Centre, Department of Horticulture, Bangladesh Agricultural University, Mymensingh, for providing logistical support during the entire period of the field experiments.

Author Contributions: Babul C. Sarker designed and carried out the experiment, analyzed data and prepared the manuscript. Mohammad A. Rahim contributed through supervision and providing necessary suggestions during the research. Douglas D. Archbold contributed in organization and presentation of the data and the manuscript, and in writing the final draft. All the authors read and approved the manuscript.

Conflicts of Interest: The authors declare no conflict of interest.

\section{References}

1. FAOSTAT. Food and Agriculture Organization of the United Nations, Statistics Division. 2016. Available online: http:/ / faostat3.fao.org/home/E (accessed on 20 June 2016).

2. Bangladesh Bureau of Statistics, Statistics Division, Planning Division, Ministry of Planning. Yearbook of Agricultural Statistics of Bangladesh; Government of the People's Republic of Bangladesh: Dhaka, Bangladesh, 2005; p. 90.

3. Reddy, Y.T.N.; Kurian, R.M.; Kohli, R.R.; Gorakh, S.; Singh, G. Effect of nitrogen, phosphorus and potassium on growth, yield and fruit quality of "Totapuri" mango (Mangifera indica). Indian J. Agric. Sci. 2000, 70, 475-478.

4. Satapathy, S.K.; Banik, B.C. Studies on nutritional requirement of mango cv. Amrapali. Orissa J. Hortic. 2002, 30,59-63.

5. Sharma, R.C.; Mahajan, B.V.C.; Dhillon, B.S.; Azad, A.S. Studies on the fertilizer requirements of mango cv. Dashehari in sub-mountainous region of Punjab. Indian J. Agric. Res. 2000, 34, 209-210.

6. Suriyapananont, V.; Subhadrabandhu, S. Fertilizer trials on mangoes (Mangifera indica L.) var. Nam Dok Mai in Thailand. Acta Hortic. 1992, 321, 529-534. [CrossRef]

7. Zhou, X.C.; Liu, G.J.; Yao, J.W.; Ai, S.Y.; Yao, L.X.; Zhou, X.C.; Liu, G.J.; Yao, J.W.; Ai, S.Y.; Yao, L.X. Balanced fertilization on mango in Southern China. Better Crops Int. 2001, 15, 16-20.

8. Khattab, M.M.; Haseeb, G.M.; Shaban, A.E.; Arafa, M.A. Effect of paclobutrazol and potassium nitrate on flowering and fruiting of Ewais and Sidik mango trees. Bull. Fac. Agric. 2006, 57, 107-123.

9. Sergent, E.; Ferrari, D.; Leal, F. Effects of potassium nitrate and Paclobutrazol on flowering induction and yield of mango (Mangifera indica L.) cv. Haden. Acta Hortic. 1997, 455, 180-187. [CrossRef]

10. Gupta, R.K.; Brahmachari, V.S. Effect of foliar application of urea, potassium nitrate and NAA on fruit retention, yield and quality of mango cv. Bombai. Orissa J. Hortic. 2004, 32, 7-9.

11. Yeshitela, T.; Robbertse, P.J.; Stassen, P.J.C. Potassium nitrate and urea sprays affect flowering and yields of "Tommy Atkins" (Mangifera indica) mango in Ethiopia. S. Afr. J. Plant Soil 2005, 22, 28-32. [CrossRef]

12. Hossain, A.K.M.A. Production Technology of Mango; Horticulture Research Centre, BARI: Gazipur, Bangladesh, 1994; p. 122.

13. Kulkarni, V.J. Chemical control of tree and promotion of flowering and fruiting in mango (Mangifera indica L.) using paclobutrazol. J. Hortic. Sci. 1988, 63, 557-566. [CrossRef]

14. Singh, S.; Singh, A.K. Regulation of shoot growth and flowering in mango cv. Gulab Khas by paclobutrazol. Ann. Agric. Res. 2006, 27, 4-8.

15. Karuna, K.; Mankar, A.; Singh, J. Effect of urea and growth substances on yield and physico-chemical characteristics of mango. Hortic. J. 2005, 18, 131-133.

16. Vijayalakshmi, D.; Srinivasan, P.S. Improving the quality attributes of "off" year Alphonso mango through chemicals and growth regulators. Orissa J. Hortic. 2000, 28, 31-33.

17. Yeshitela, T.; Robbertse, P.J.; Stassen, P.J.C. Paclobutrazol suppressed vegetative growth and improved yield as well as fruit quality of "Tommy Atkins" mango (Mangifera indica) in Ethiopia. N. Z. J. Crop Hortic. Sci. 2004, 32, 281-293. [CrossRef]

18. Sarker, B.C.; Rahim, M.A. Effects of doses and splits of fertilizer application on harvesting time, yield and quality of mango cv. Amrapali. Bangladesh J. Agric. Res. 2012, 37, 279-293. [CrossRef]

19. Sarker, B.C.; Rahim, M.A. Yield and quality of mango (Mangifera indica L.) as influenced by foliar application of potassium nitrate and urea. Bangladesh J. Agric. Res. 2013, 38, 145-154. [CrossRef]

20. Singh, L.B. The Mango Botany, Cultivation and Utilization; Leonard Hill Ltd.: London, UK, 1968; p. 230. 
21. Sarker, B.C.; Rahim, M.A. Effect of irrigation frequency on harvesting time, yield and quality of mango. J. Bangladesh Soc. Agric. Sci. Technol. 2010, 7, 11-16.

22. United Nations Development Programme (UNDP). Land Resource Appraisal of Bangladesh for Agricultural Development Report 2: Agroecological Regions of Bangladesh; Food And Agriculture Organization (FAO): Rome, Italy, 1988; p. 577.

23. Singh, R.N. Mango; Indian Council of Agricultural Research: New Delhi, India, 1996; p. 134.

24. Burondkar, M.M.; Gunjate, R.T. Control of vegetative growth and induction of regular and early cropping in "Alphonso" mango with paclobutrazol. Acta Hortic. 1993, 341, 206-215. [CrossRef]

25. Rangana, S. Manual of Analysis of Fruit and Vegetable Products; Tata McGraw-Hill Pub. Co. Ltd.: New Delhi, India, 1979; p. 634.

26. Plummer, D.T. An Introduction to Practical Biochemistry; Tata McGraw-Hill Pub. Co. Ltd.: New Delhi, India, 1971; p. 229.

27. Miller, G.L. Use of dinitro salicylic acid reagent for determination of reducing sugar. Anal. Chem. 1972, 31, 426-428. [CrossRef]

28. Jayaraman, J. Laboratory Manual in Biochemistry; Wiley Eastern Ltd.: New Delhi, India, 1981; p. 62.

29. Gomez, K.A.; Gomez, A.A. Statistical Procedures for Agricultural Research; John Wiley and Sons: New York, NY, USA, 1984; p. 680.

30. Sarker, B.C.; Rahim, M.A. Vegetative growth, harvesting time, yield and quality of mango (Mangifera indica L.) as influenced by soil drench application of paclobutrazol. Bangladesh J. Agric. Res. 2012, 37, 335-348. [CrossRef]

31. Kurian, R.M.; Iyer, C.P.A. Stem anatomical characteristics in relation to tree vigour in mango (Mangifera indica L.). Sci. Hortic. 1992, 50, 245-253. [CrossRef]

32. Cardenas, K.; Rojas, E. Effect of paclobutrazol and nitrates of potassium and calcium on the development of the mango "Tommy Atkins". Bioagro 2003, 15, 83-90.

33. Ram, S. Hormonal physiology of flowering in "Dashehari" mango. J. Appl. Hortic. 1999, 1, 84-88.

34. Jogdande, N.D.; Choudhari, K.G. Seasonal changes in auxin content and its role in flowering of mango (Mangifera indica L.). Orissa J. Hortic. 2001, 29, 10-12.

35. Dalal, S.R.; Gonge, V.S.; Jadhao, B.J.; Jogdande, N.D. Effect of chemical on flowering and fruit yield of mango cv. Pairy. Int. J. Agric. Sci. 2005, 1, $24-25$.

36. Mosqueda-Vazquez, R.; Avila-Resendiz, C. Floral induction of mango with $\mathrm{KNO}_{3}$ applications and its inhibition by $\mathrm{AgNO}_{3}$ or $\mathrm{CoCl}_{2}$ application. Hortic. Mex. 1985, 1, 93-101.

37. Singh, D.B.; Ranganath, H.R. Induction of regular and early fruiting in mango by paclobutrazol under tropical humid climate. Indian J. Hortic. 2006, 63, 248-250.

38. Quinlan, J.D. New approaches to the control of fruit tree forms and size. Acta Hortic. 1981, 120, 95-105. [CrossRef]

39. Singh, Z.; Dhillon, B.S. Effect of paclobutrazol on floral malformation, yield and quality of mango (Mangifera indica L.). Acta Hortic. 1992, 296, 51-53. [CrossRef]

40. Shinde, A.K.; Waghmare, G.M.; Wagh, R.G.; Burondkar, M.M. Effect of dose and time of paclobutrazol application on flowering and yield of mango. Indian J. Plant Physiol. 2000, 5, 82-84.

41. Anbu, S.; Parthiban, S.; Rajangam, J.; Thangaraj, T. Induction of off-season flowering in mango (Mangifera indica L.) using paclobutrazol. South Indian Hortic. 2002, 49, 384-385.

42. Oosthuyse, S.A. Effect of $\mathrm{KNO}_{3}$ sprays to flowering mango trees on fruit retention, fruit size, tree yield and fruit quality. Acta Hortic. 1997, 455, 359-366. [CrossRef]

43. Feungchan, S.; Yimsawat, T.; Chindaprasert, S.; Hongsbhanich, N.; Daito, H. The effect of the fertilizer application interval on the mango. Kaen Kaset Khon Kaen Agric. J. 1989, 17, 100-105.

44. Ghosh, S.N.; Chattopadhyay, N. Foliar application of urea on yield and physico-chemical composition of mango fruits cv. Himsagar under rainfed condition. Hortic. J. 1999, 12, $21-24$.

45. Sarker, B.C.; Rahim, M.A.; Pomology Division, Horticulture Research Centre, Bangladesh Agricultural Research Institute, Joydebpur, Gazipur 1701, Bangladesh. Unpublished Data, 2012.

(C) 2016 by the authors; licensee MDPI, Basel, Switzerland. This article is an open access article distributed under the terms and conditions of the Creative Commons Attribution (CC-BY) license (http://creativecommons.org/licenses/by/4.0/). 